\title{
An evaluation of total and digestible lysine as a predictor of lysine availability in protein concentrates for young pigs
}

\author{
BY JANE LEIBHOLZ \\ Department of Animal Husbandry, University of Sydney, \\ Camden, New South Wales 2570, Australia
}

(Received 7 June 1984 - Accepted 11 December 1984)

1. Forty pigs between 23 and $51 \mathrm{~d}$ of age were given, ad lib., diets containing $7.9 \mathrm{glysine} / \mathrm{kg}$. The diets contained wheat and one of five protein concentrates: milk, peanut (Arachis hypogaea) meal, cotton-seed (Gossypium herbaceum) meal, meat meal or lupins (Lupinus augustifolius).

2. Twenty of the pigs were given an indigestible marker, ${ }^{103} \mathrm{Ru}$-labelled Tris-(1,10-phenanthroline)-ruthenium(II) chloride, between 51 and $56 \mathrm{~d}$ of age and were killed at $56 \mathrm{~d}$ of age.

3. A further forty pigs, between 23 and $51 \mathrm{~d}$ of age, were given the same diets supplemented with $3 \mathrm{~g} \mathrm{L-lysine}$ hydrochloride $/ \mathrm{kg}$.

4. The weight gains of the pigs given the diets containing $7.9 \mathrm{~g}$ lysine $/ \mathrm{kg}(95-153 \mathrm{~g} / \mathrm{d})$ were significantly less $(P<0.05)$ than those of the pigs given the diets containing $10.9 \mathrm{~g}$ lysine $/ \mathrm{kg}(274-340 \mathrm{~g} / \mathrm{d})$.

5. Weight gains of pigs given the diets containing meat meal were less than those of pigs given diets containing milk, peanut meal or lupins.

6. Feed conversion ratios decreased and $\mathrm{N}$ balances increased with increasing lysine content of the diets.

7. Apparent digestibilities of dry matter (DM) and nitrogen of the diets containing meat meal and cotton-seed meal were less than those of the other three diets, but there was no effect of lysine content of the diets on these indices.

8. The major site of $\mathrm{DM}$ and $\mathrm{N}$ absorption for the diet containing milk was the duodenum while for the other four protein concentrates the jejunum and ileum were the major absorption sites.

9. Apparent digestibility of lysine from the five diets ranged from 0.54 to 0.75 . The retention of the apparently absorbed lysine in weight gain was $0.86-0.94$, and there was no significant $(P>0.05)$ difference between diets which suggested that the apparent digestibility of lysine could be an indicator of its availability.

Lysine is normally the first limiting amino acid in cereal-based diets for growing pigs although, for young pigs, lysine, methionine, tryptophan and threonine may be jointly the first limiting. These limitations may be overcome by a suitable mixture of protein concentrates in the diets or supplementation of the diets with free amino acids.

In addition to knowledge of the total amino acid content of diets, the availability of the amino acids must also be determined. Studies with lysine have shown its availability for carcass gain to be $0.39,0.50$ and 0.88 for cotton-seed meal, meat meal and milk protein respectively (Batterham et al. 1979). These values were obtained by slope-ratio assays with growing pigs. On the other hand, the disappearance of dietary lysine from meat meal and peanut meal to the terminal ileum was found to be 0.77 and 0.84 respectively (Alimon \& Farrell, 1980). Taken together, these results would suggest poor utilization of absorbed lysine.

In the present experiment, the apparent digestibility of lysine in five protein concentrates was measured to the ileum in young pigs, and this was directly related to the estimated retention of lysine in carcass gain.

\section{MATERIALS AND METHODS}

\section{Diets}

Five diets (diets 1-5) were formulated to contain $7.9 \mathrm{~g}$ lysine $/ \mathrm{kg}$ (Table 1 ) which is about $83 \%$ of the lysine requirement of $5-10-\mathrm{kg}$ pigs ((US) National Research Council, 1979). The 
diets contained wheat and one of five protein concentrates: spray-dried skim-milk, meat meal $(500 \mathrm{~g}$ crude protein (nitrogen $\times 6.25 ; \mathrm{CP}) / \mathrm{kg}$ ), peanut (Arachis hypogaea) meal, cotton-seed (Gossypium herbaceum) meal and dehulled lupins (Lupinus augustifolius cv. Unicrop). The CP content of the diets was $167-206 \mathrm{~g} / \mathrm{kg}$ and the requirement ((US) National Research Council, 1979) of all essential amino acids except lysine was met by the diets. A further five diets (diets 6-10) had the same composition as diets 1-5 except that each was supplemented with $3 \mathrm{~g}$ L-lysine $/ \mathrm{kg}$.

\section{Animals and management}

A total of eighty entire, male Large White $\times$ Landrace pigs, in two groups of forty, were weaned at $20 \mathrm{~d}$ of age and housed in tiered cages in groups of ten for a preliminary period of $3 \mathrm{~d}$.

At $23 \mathrm{~d}$ of age (average weight $5.7 \mathrm{~kg}$ ) the pigs were allocated to the ten experimental diets (Table 1), one pig per pen. Randomized block designs were used, with each block consisting of pigs of a similar age and weight. The diets were offered ad lib. and water was available from nipple drinkers. Fresh food was offered daily. The pigs and any uneaten food residues were weighed weekly. The duration of the experiment was $28 \mathrm{~d}$.

The cages were in a draught-free room maintained at $26^{\circ}$. Artificial lighting was continuous at a low intensity. No mortalities occurred during the experiments.

Faeces were collected on screens above sloping trays, which drained the urine into bottles containing $200 \mathrm{ml}$ hydrochloric acid $(5 \mathrm{~mol} / \mathrm{l})$. The collection period was from 45 to $51 \mathrm{~d}$ of age. Twenty pigs were given diets 1-5 (four pigs per diet) and indigestible marker was sprayed onto their diets when the pigs were $51-56 \mathrm{~d}$ of age. Feed was restricted to about $90 \%$ of the $a d l i b$. intake and offered in twenty-four equal hourly portions. The marker used during this period was ${ }^{103} \mathrm{Ru}$-labelled Tris-(1,10-phenanthroline)-ruthenium(II)chloride and details of the procedures were described by Wilson \& Leibholz (1981a). The intake of the isotope was approximately $2.5 \mu \mathrm{Ci} /$ pig per $\mathrm{d}$.

At $56 \mathrm{~d}$ of age and exactly $15 \mathrm{~min}$ after an hourly feeding, the pigs were anaesthetized by intravenous administration of Surital (sodium thiamylal; Parke Davis \& Co., Sydney). The intestinal tract was removed under these conditions to prevent, as much as possible, the shedding of epithelium into the intestinal lumen. The length of the small intestine was measured and then divided into three equal parts (designated duodenum, jejunum and ileum). All digesta were rapidly removed from the intestines, stomach, caecum and colon, and weighed. Digesta were stored at $-20^{\circ}$ following $\mathrm{pH}$ determination.

\section{Analytical methods}

Digesta samples were homogenized and the samples counted in an Auto Gamma Spectrophotometer (Model 5320; Packard Instrument Co. Inc., Ill.). Dry matter (DM) was determined in a forced-air oven at $95^{\circ}$. Amino acids in feed and digesta samples were determined using ion-exchange chromatography (TSM Amino Acid AutoAnalyzer; Technicon Equipment Ltd, Sydney). Samples were oxidized with performic acid and hydrolysed in $6 \mathrm{M}-\mathrm{HCl}$ for $24 \mathrm{~h}$ at $136^{\circ}$. Total $\mathrm{N}$ was determined by the Kjeldahl method.

\section{Statistical analysis}

The data were subjected to analysis of variance and least significant differences $(P<0.05)$ were used to compare means statistically (Steel \& Torrie, 1960).

The standard errors were calculated as $\sqrt{ }(\mathrm{EMS}) / n$ where $n$ was 16 for protein source, 40 for lysine supplement and 8 for interaction in Table 2. The value of $n$ in all other tables was 4. 
Table 1. Composition of experimental diets

\begin{tabular}{|c|c|c|c|c|c|}
\hline Diet*... & 1 & 2 & 3 & 4 & 5 \\
\hline \multicolumn{6}{|l|}{ Ingredients ( $\mathrm{g} / \mathrm{kg}$ air dry) } \\
\hline Wheat & 804 & 602 & 624 & 795 & 699 \\
\hline Dried skim milk & 150 & - & - & - & - \\
\hline Glycine & 20 & - & - & - & - \\
\hline Premix $\dagger$ & 5 & 5 & 5 & 5 & 5 \\
\hline Peanut (Arachis hypogaea) meal & - & 340 & - & - & - \\
\hline Catton-seed (Gossypium herbaceum) meal & - & - & 320 & - & - \\
\hline Meat meal & - & 一 & - & 170 & - \\
\hline Lupins (Lupinus augustifolius) & - & - & - & - & 270 \\
\hline Calcium dihydrogen phosphate & 11 & 11 & 6 & - & 11 \\
\hline Calcium carbonate & 10 & 12 & 15 & - & 15 \\
\hline Methionine & 1.4 & 1.4 & $1 \cdot 2$ & $1 \cdot 3$ & $2 \cdot 2$ \\
\hline Tallow & - & 30 & 30 & 30 & - \\
\hline \multicolumn{6}{|l|}{ Chemical composition ( $\mathrm{g} / \mathrm{kg}$ of air-dry diet) } \\
\hline Nitrogen & $26 \cdot 8$ & $32 \cdot 9$ & $32 \cdot 0$ & $29 \cdot 7$ & 29.9 \\
\hline Methionine & $3 \cdot 0$ & $3 \cdot 0$ & $3 \cdot 0$ & $3 \cdot 0$ & $3 \cdot 0$ \\
\hline Lysine & $7 \cdot 9$ & 7.9 & 7.9 & 7.9 & 7.9 \\
\hline Tryptophan & $2 \cdot 1$ & $2 \cdot 7$ & $3 \cdot 0$ & $2 \cdot 0$ & $2 \cdot 0$ \\
\hline Threonine & 5.8 & $6 \cdot 1$ & 6.9 & $5 \cdot 7$ & $6 \cdot 1$ \\
\hline \multicolumn{6}{|l|}{ Calculated analysis } \\
\hline Calcium $(\mathrm{g} / \mathrm{kg})$ & $8 \cdot 3$ & $8: 0$ & 7.9 & $17 \cdot 4$ & 8.0 \\
\hline Phosphorus $(\mathrm{g} / \mathrm{kg})$ & $6 \cdot 1$ & $6 \cdot 1$ & $6 \cdot 1$ & 11.0 & $6 \cdot 1$ \\
\hline Digestible energy $(\mathrm{MJ} / \mathrm{kg}$ ) & 13.8 & $13 \cdot 5$ & $13 \cdot 5$ & 13.6 & $13 \cdot 3$ \\
\hline
\end{tabular}

* Diets 6-10 had the same composition as diets $1-5$ respectively, except that each diet was supplemented with $3 \mathrm{~g}$ lysine $/ \mathrm{kg}$.

$\dagger$ Added to supply (mg/kg diet): 1.5 retinol, 0.025 choleacalciferol, $24 \alpha$-tocopherol, 7 riboflavin, 24 niacin, 12 pantothenic acid, 0.12 biotin, $700 \mathrm{Na}, 100 \mathrm{Fe}, 10 \mathrm{Cu}, 30 \mathrm{Mn}, 100 \mathrm{Zn}, 40$ oxytetracycline, 100 butylated hydroxytoluene.

\section{RESULTS}

\section{Performance of pigs}

The mean weight gains of the pigs given the diets containing $7.9 \mathrm{~g}$ lysine $/ \mathrm{kg}$ varied from $95 \mathrm{~g} / \mathrm{d}$ for the diet containing meat meal to $153 \mathrm{~g} / \mathrm{d}$ for the diet containing milk (Table 2) and this difference was significant $(P<0.05)$. Also, the mean feed conversion ratios significantly decreased $(P<0.05)$ and, although mean daily $\mathrm{N}$ retentions increased, this increase was not significant $(P>0.05)$.

The addition of $3 \mathrm{~g}$ lysine $/ \mathrm{kg}$ diet significantly $P<0.05$ ) increased the growth rates and daily $\mathrm{N}$ retentions and significantly $(P<0.05)$ decreased the feed conversion ratios in the pigs given all five protein concentrates.

The apparent digestibilities of DM and $\mathrm{N}$ were significantly $(P<0.05)$ lower for the diets containing meat meal and cotton-seed meal than those for the diets containing the other three protein concentrates. The apparent digestibilities of $\mathrm{N}$ and $\mathrm{DM}$ were unaffected by the lysine content of the diets.

\section{Digestion of $D M$}

During the final period of the experiment the feed intake of the pigs given meat meal as the protein concentrate was less than that of the other pigs (Table 3 ), but the differences were not significant $(P>0.05)$. There was no apparent digestion of DM in the stomach but $7 \cdot 7-47 \cdot 4 \%$ of the total apparent digestion of DM occurred in the duodenum. 
Table 2. The performance of pigs from 23-51 d of age given five protein concentrates at 7.9 or $10.9 \mathrm{~g}$ lysine $/ \mathrm{kg}$ diet $\dagger$

\begin{tabular}{|c|c|c|c|c|c|c|}
\hline \multirow{2}{*}{$\begin{array}{c}\text { Lysine } \\
\text { (g/kg } \\
\text { diet) }\end{array}$} & \multirow{2}{*}{$\begin{array}{c}\text { Protein } \\
\text { concentrate }\end{array}$} & \multirow{2}{*}{$\begin{array}{l}\text { Wt gain } \\
(\mathrm{g} / \mathrm{d})\end{array}$} & \multirow{2}{*}{$\begin{array}{l}\text { Feed } \\
\text { conversion } \\
\text { ratio }\end{array}$} & \multirow{2}{*}{$\begin{array}{l}\text { Nitrogen } \\
\text { retention } \\
(\mathrm{g} / \mathrm{d})\end{array}$} & \multicolumn{2}{|c|}{ Apparent digestibility } \\
\hline & & & & & Dry matter & $\mathrm{N}$ \\
\hline \multirow[t]{6}{*}{$7 \cdot 9$} & Milk & 153 & $2 \cdot 18$ & 4.94 & 0.878 & 0.881 \\
\hline & $\begin{array}{l}\text { Peanut (Arachis hypogaea) meal } \\
\text { Cotton-seed (Gossypium herbaceum) }\end{array}$ & 134 & $2 \cdot 08$ & $4 \cdot 72$ & 0.857 & $0-884$ \\
\hline & meal & 123 & $2 \cdot 37$ & $4 \cdot 40$ & 0.800 & 0.821 \\
\hline & Meat meal & 95 & $2 \cdot 62$ & $4 \cdot 22$ & 0.805 & $0 \cdot 816$ \\
\hline & Lupins (Lupinus augustifolius) & 142 & $2 \cdot 16$ & $4 \cdot 52$ & 0.862 & $0-881$ \\
\hline & Mean & 129 & $2 \cdot 30$ & $4 \cdot 56$ & 0.840 & 0.857 \\
\hline \multirow[t]{10}{*}{$10 \cdot 9$} & Milk & 321 & $1 \cdot 60$ & 11.05 & 0.895 & 0.902 \\
\hline & Peanut meal & 324 & 1.69 & $12 \cdot 50$ & 0.849 & 0.871 \\
\hline & Cotton-seed meal & 308 & 1.73 & $8 \cdot 62$ & 0.764 & 0.775 \\
\hline & Meat meal & 274 & 1.85 & $9 \cdot 34$ & 0.799 & 0.796 \\
\hline & Lupins & 340 & 1.53 & $11 \cdot 01$ & $0-882$ & 0.877 \\
\hline & Mean & 313 & 1.68 & $10 \cdot 50$ & $0 \cdot 837$ & 0.844 \\
\hline & SEM due to: & & & & & \\
\hline & Protein source & $18 \cdot 6^{*}$ & $0 \cdot 112 *$ & 0.707 & $0.0113^{*}$ & $0.0108^{*}$ \\
\hline & Lysine & $11 \cdot 7^{*}$ & $0.071^{*}$ & $0 \cdot 447^{*}$ & 0.0071 & 0.0068 \\
\hline & Interaction & $26 \cdot 2$ & $0 \cdot 160$ & 1.001 & $0 \cdot 0159$ & 0.0152 \\
\hline
\end{tabular}

* $P<0.05$.

$\dagger$ For details of diet composition, see Table 1 .

Table 3. The flow of dry matter (DM) and DM digestion in pigs, $56 \mathrm{~d}$ of age, given five protein concentrates of $7.9 \mathrm{~g}$ lysine $/ \mathrm{kg}$ diet

\begin{tabular}{|c|c|c|c|c|c|c|}
\hline \multirow[b]{2}{*}{ Protein concentrate } & 1 & 2 & 3 & 4 & 5 & \multirow[b]{2}{*}{ SEM } \\
\hline & Milk & $\begin{array}{c}\text { Peanut } \\
\text { (Arachis } \\
\text { hypogaea) } \\
\text { meal }\end{array}$ & $\begin{array}{c}\text { Cotton-seed } \\
\text { (Gossypium } \\
\text { herbaceum) } \\
\text { meal }\end{array}$ & $\begin{array}{l}\text { Meat } \\
\text { meal }\end{array}$ & $\begin{array}{c}\text { Lupins } \\
\text { (Lupinus } \\
\text { augistifolius) }\end{array}$ & \\
\hline DM intake (g/d) & 336 & 331 & 355 & 291 & 371 & $39 \cdot 8$ \\
\hline \multicolumn{7}{|l|}{$\begin{array}{l}\text { DM flow } \\
\text { in intestinal } \\
\text { section }(g / d)\end{array}$} \\
\hline Stomach & 368 & 328 & 356 & 303 & 371 & $42 \cdot 8$ \\
\hline Duodenum & 215 & 286 & 325 & 286 & 310 & $30 \cdot 1$ \\
\hline Jejunum & 142 & 168 & 206 & 208 & 173 & $29 \cdot 9$ \\
\hline Ileum & 97 & 98 & 125 & 128 & 102 & $14 \cdot 5$ \\
\hline Caecum & 61 & 64 & 100 & 93 & 63 & 8.9 \\
\hline Large intestine & 47 & 49 & 81 & 77 & 50 & 7.6 \\
\hline Faeces & 43 & 46 & 73 & 70 & 46 & $5 \cdot 9$ \\
\hline \multicolumn{7}{|l|}{$\begin{array}{l}\text { Percentage of } \\
\text { apparent digestion } \\
\text { occurring in: }\end{array}$} \\
\hline Stomach & -1 & 1 & 0 & -5 & 0 & $4 \cdot 6$ \\
\hline Duodenum & 47 & 15 & 11 & 8 & 19 & $6 \cdot 6^{*}$ \\
\hline Jejunum & 23 & 41 & 42 & 35 & 42 & $6 \cdot 5^{*}$ \\
\hline Ileum & 14 & 25 & 29 & 36 & 22 & $4 \cdot 1^{*}$ \\
\hline Caecum & 11 & 12 & 9 & 14 & 12 & $3 \cdot 9$ \\
\hline Large intestine: 1 & 4 & 5 & 7 & 7 & 4 & 3.7 \\
\hline 2 & 1 & 1 & 3 & 3 & 1 & $2 \cdot 5$ \\
\hline
\end{tabular}

* $P<0.05$.

+ For details of diet composition, see Table 1. 
Table 4. The flow of nitrogen and $N$ digestion in pigs, $56 \mathrm{~d}$ of age, given five protein concentrates at $7.9 \mathrm{~g}$ lysine $/ \mathrm{kg}$ diet

\begin{tabular}{|c|c|c|c|c|c|c|}
\hline \multirow[b]{2}{*}{ Protein concentrate ... } & 1 & 2 & 3 & 4 & 5 & \multirow[b]{2}{*}{ SEM } \\
\hline & Milk & $\begin{array}{c}\text { Peanut } \\
\text { (Arachis } \\
\text { hypogaea) } \\
\text { meal }\end{array}$ & $\begin{array}{c}\text { Cotton- } \\
\text { seed } \\
\text { (Gossypium } \\
\text { herbaceum) } \\
\text { meal }\end{array}$ & $\begin{array}{l}\text { Meat } \\
\text { meal }\end{array}$ & $\begin{array}{c}\text { Lupins } \\
\text { (Lupinus } \\
\text { augustifolius) }\end{array}$ & \\
\hline $\begin{array}{l}\mathrm{N} \text { intake }(\mathrm{g} / \mathrm{d}) \\
\mathrm{N} \text { flow } \\
\text { in intestinal } \\
\text { section }(\mathrm{g} / \mathrm{d})\end{array}$ & $10 \cdot 8$ & $12 \cdot 4$ & $11 \cdot 7$ & $9 \cdot 1$ & $10 \cdot 8$ & $1 \cdot 12^{*}$ \\
\hline Stomach & $11 \cdot 0$ & 11.0 & 11.9 & 9.5 & $10 \cdot 5$ & $1 \cdot 12$ \\
\hline Duodenum & 6.8 & $10 \cdot 0$ & $11 \cdot 5$ & $9 \cdot 2$ & $9 \cdot 7$ & $1 \cdot 18^{*}$ \\
\hline Jejunum & 4.0 & $6 \cdot 1$ & 6.0 & 7.0 & 5.9 & $0.56^{*}$ \\
\hline Hleum & $2 \cdot 4$ & $2 \cdot 4$ & $3 \cdot 2$ & $3 \cdot 6$ & $2 \cdot 4$ & $0 \cdot 34^{*}$ \\
\hline Caecum & 1.7 & $2 \cdot 3$ & $2 \cdot \overline{6}$ & $2 \cdot 9$ & 1.8 & $0.27^{*}$ \\
\hline Large intestine & $1 \cdot 3$ & 1.7 & $2 \cdot 3$ & $2 \cdot 4$ & $1 \cdot 3$ & $0.26^{*}$ \\
\hline Faeces & $1 \cdot 0$ & 1.5 & 1.9 & 1.9 & $1 \cdot 3$ & $0 \cdot 17^{*}$ \\
\hline \multicolumn{7}{|l|}{$\begin{array}{l}\text { Percentage of } \\
\text { apparent digestion }\end{array}$} \\
\hline Stomach & -1 & 13 & -1 & -6 & 3 & $3 \cdot 6^{*}$ \\
\hline Duodenum & 42 & 9 & 4 & 5 & 9 & $4 \cdot 9^{*}$ \\
\hline Jejunum & 28 & 36 & 56 & 30 & 39 & $5 \cdot 0^{*}$ \\
\hline Ileum & 16 & 33 & 70 & 47 & 37 & $4 \cdot 9 *$ \\
\hline Caecum & 7 & 2 & 6 & 11 & 7 & $3 \cdot 1$ \\
\hline Large intestine: 1 & 4 & 6 & 3 & 7 & 5 & $2 \cdot 0$ \\
\hline 2 & 3 & 2 & 3 & 7 & 1 & 1.8 \\
\hline
\end{tabular}

$* P<0.05$.

$\dagger$ For details of diet composition, see Table 1.

Table 5. The flow of lysine $(\mathrm{g} / \mathrm{d})$ in pigs, $56 \mathrm{~d}$ of age, given five protein concentrates at $7.9 \mathrm{~g}$ lysine $/ \mathrm{kg}$ diet

\begin{tabular}{|c|c|c|c|c|c|c|}
\hline Diet $† \ldots$ & 1 & 2 & 3 & 4 & 5 & \\
\hline $\begin{array}{l}\text { Protein } \\
\text { concentrate ... }\end{array}$ & Milk & $\begin{array}{c}\text { Peanut } \\
\text { (Arachis } \\
\text { hypogaea) } \\
\text { meal }\end{array}$ & $\begin{array}{c}\text { Cotton- } \\
\text { seed } \\
\text { (Gossypium } \\
\text { herbaceum) } \\
\text { meal }\end{array}$ & $\begin{array}{l}\text { Meat } \\
\text { meal }\end{array}$ & $\begin{array}{c}\text { Lupins } \\
\text { (Lupinus } \\
\text { augustifolius) }\end{array}$ & SEM \\
\hline Intake & $3 \cdot 17$ & $2 \cdot 87$ & 3.08 & $2 \cdot 51$ & $3 \cdot 21$ & $0 \cdot 344$ \\
\hline Stomach & $3 \cdot 34$ & $2 \cdot 52$ & $2 \cdot 68$ & $2 \cdot 68$ & $3 \cdot 27$ & 0.363 \\
\hline Duodenum & $2 \cdot 47$ & 2.99 & $2 \cdot 88$ & $2 \cdot 52$ & 3.31 & $0 \cdot 367$ \\
\hline Jejunum & $1 \cdot 74$ & $2 \cdot 37$ & $2 \cdot 69$ & $2 \cdot 26$ & $2 \cdot 13$ & $0 \cdot 390$ \\
\hline Ileum & 0.95 & 0.78 & $1 \cdot 21$ & $1 \cdot 15$ & 0.81 & $0 \cdot 173^{*}$ \\
\hline Caecum & 0.88 & 0.67 & $1 \cdot 09$ & 0.97 & 0.71 & $0 \cdot 130^{*}$ \\
\hline Large intestine & $0 \cdot 70$ & 0.68 & 0.82 & $0 \cdot 89$ & 0.55 & $0.091 *$ \\
\hline
\end{tabular}

+ For details of diet composition, see Table 1 . 


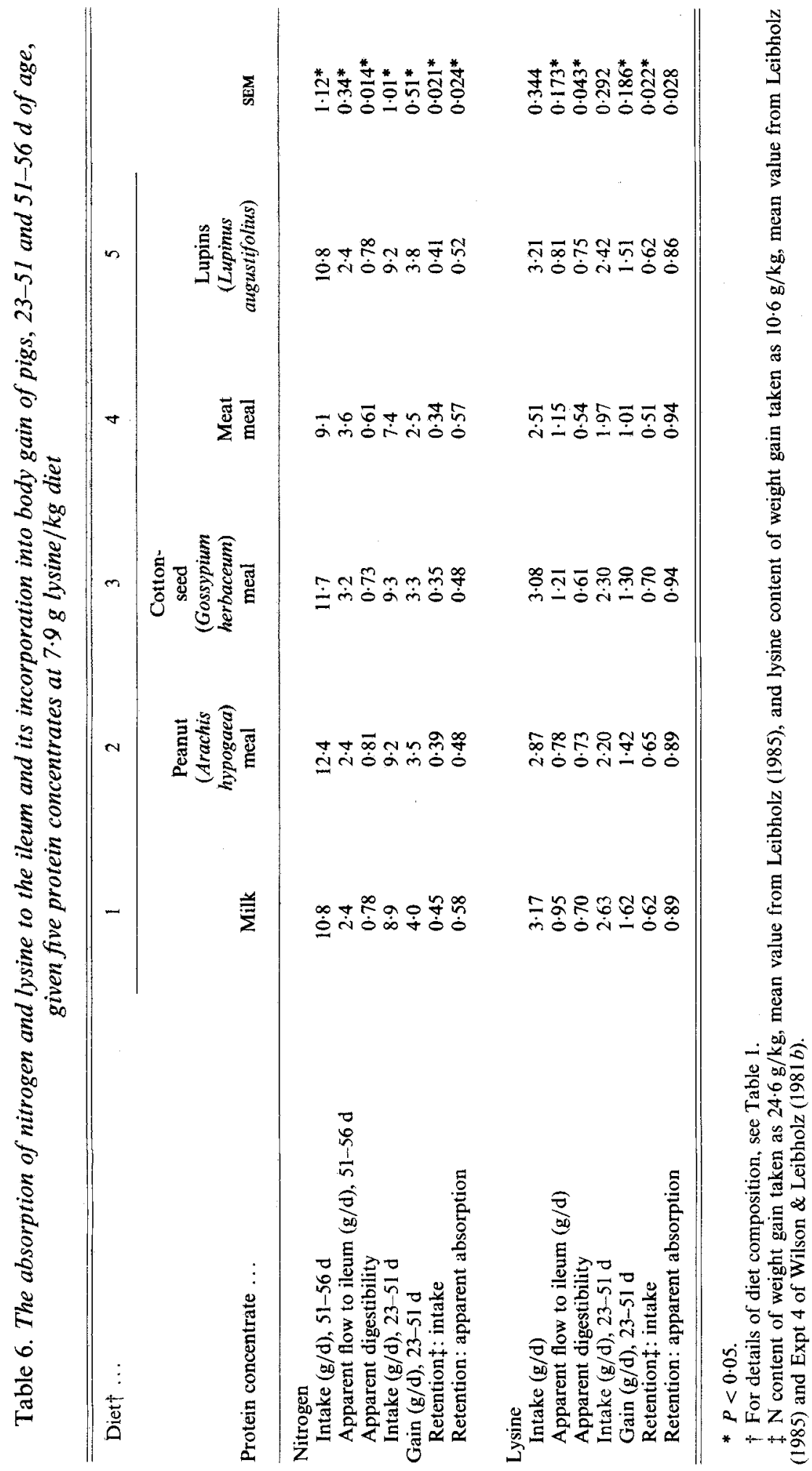


Table 7. The apparent digestibilities of nitrogen and essential amino acids to the ileum in pigs, 23-51 d of age, given five protein concentrates at $7.9 \mathrm{~g}$ lysine $/ \mathrm{kg}$ diet

\begin{tabular}{|c|c|c|c|c|c|c|}
\hline Diet $\dagger \ldots$ & 1 & 2 & 3 & 4 & 5 & \\
\hline $\begin{array}{l}\text { Protein } \\
\text { concentrate ... }\end{array}$ & Milk & $\begin{array}{c}\text { Peanut } \\
\text { (Archis } \\
\text { hypogaea) } \\
\text { meal }\end{array}$ & $\begin{array}{c}\text { Cotton- } \\
\text { seed } \\
\text { (Gossypium } \\
\text { herbaceum) } \\
\text { meal }\end{array}$ & $\begin{array}{l}\text { Meat } \\
\text { meal }\end{array}$ & $\begin{array}{c}\text { Lupins } \\
\text { (Lupinus } \\
\text { augustifolius) }\end{array}$ & SEM \\
\hline Nitrogen & 0.78 & 0.81 & 0.73 & 0.61 & 0.78 & $0.014^{*}$ \\
\hline Lysine & 0.70 & 0.73 & 0.61 & 0.54 & 0.75 & $0.043^{*}$ \\
\hline Methionine & 0.79 & 0.79 & 0.68 & 0.67 & 0.81 & $0.033^{*}$ \\
\hline Threonine & 0.78 & 0.75 & 0.69 & 0.63 & 0.74 & $0.049^{*}$ \\
\hline Isoleucine & 0.77 & 0.76 & 0.69 & 0.62 & 0.80 & $0.040^{*}$ \\
\hline Leucine & 0.83 & 0.83 & 0.75 & 0.69 & 0.83 & 0.049 \\
\hline Valine & 0.72 & 0.74 & 0.65 & 0.60 & 0.75 & 0.043 \\
\hline Tyrosine & 0.89 & 0.87 & 0.78 & 0.77 & 0.88 & 0.038 \\
\hline Phenylalanine & 0.82 & 0.77 & 0.77 & 0.70 & 0.81 & 0.039 \\
\hline Histidine & 0.78 & 0.77 & 0.69 & 0.72 & 0.80 & 0.045 \\
\hline Arginine & 0.72 & 0.74 & 0.65 & 0.68 & 0.76 & 0.040 \\
\hline
\end{tabular}

$* P<0.05$.

$\dagger$ For details of diet composition, see Table 1.

The major site of DM digestion of the diet containing milk was the duodenum, while that of the diets containing peanut meal, cotton-seed meal and lupins was the jejunum and of the diet containing meat meal, the jejunum and ileum. Between 9 and $14 \%$ of the apparent DM digestion occurred in the caecum and $5-10 \%$ in the large intestines, and there were some differences between diets.

\section{Digestion of $N$ and lysine}

There were significant $(P<0.05)$ differences in the $\mathrm{N}$ intakes and the flows of $\mathrm{N}$ in the digestive tract between the five protein concentrates (Table 4). The major sites of digestion of the $\mathbf{N}$ from the five diets were similar to the sites of DM digestion. Again, the milk protein was largely digested in the duodenum while the other protein concentrates were largely digested in the jejunum and in the ileum.

The average apparent digestion of $\mathrm{N}$ in the ileum was significantly $(P<0.05)$ greater than that of DM $(32.7 v .22 .2 \%)$ while it was significantly $(P<0.05)$ less in the duodenum. The apparent digestion of $\mathrm{N}$ in the caecum was significantly $(P<0.05)$ less than that of DM $(6.4 v .11 .9 \%)$.

The apparent flow of lysine in the digestive tract was not significantly different for the five protein concentrates before the ileum. There was a greater flow of lysine to the ileum for the pigs given meat meal and cotton-seed meal than for those given the other three protein concentrates (Table 5).

In Table 6 , it can be seen that the apparent digestibility of $\mathrm{N}$ to the ileum was 0.61 for pigs given meat meal, which was significantly lower than the apparent digestibility of $N$ to the ileum for pigs given milk, peanut meal or lupins. The apparent digestibility of lysine in pigs given milk was significantly $(P<0.05)$ greater than that of pigs given meat meal. Using the measured apparent digestibility values of $\mathrm{N}$ and lysine to the ileum and the weight gain of the pigs from 23 to $51 \mathrm{~d}$ of age, it was calculated that the retention of apparently absorbed $\mathrm{N}$ in weight gain was $0.48-0.58$ while that of lysine was $0.86-0.94$. 
The apparent digestibilities to the ileum of methionine, threonine and isoleucine in meat meal and cotton-seed meal were significantly less $(P<0.05)$ than those of the other three protein concentrates (Table 7), but there were no significant differences $(P>0.05)$ for the other essential amino acids.

\section{DISCUSSION}

Five protein concentrates were compared on an equal total lysine basis with all diets containing $7.9 \mathrm{~g}$ lysine $/ \mathrm{kg}$ which is $83 \%$ of the lysine requirement of pigs between 5 and $10 \mathrm{~kg}$ live weight ((US) National Research Council, 1979). About one-third of the lysine came from wheat and two-thirds from the protein concentrates. The $62 \%$ difference in growth rates of pigs given the diets containing meat meal and milk may indicate a substantial difference in the availability of lysine from these two protein concentrates, although part of the difference may also be explained by a feed intake of $334 \mathrm{~g} / \mathrm{d}$ for the pigs given the milk diet and $249 \mathrm{~g} / \mathrm{d}$ for the pigs given the meat-meal diet. Batterham et al. (1978) observed differences in weight gains of growing pigs of $12 \%$ between these concentrates when lysine was supplied at $6.1 \mathrm{~g} / \mathrm{kg}$ diet. The greater difference in the present experiment could also be explained by a higher lysine requirement of the younger pigs as indicated by an average growth response (for all diets) of $61.3 \mathrm{~g} / \mathrm{d}$ for each gram of supplemented lysine compared with a response of only $38.5 \mathrm{~g} / \mathrm{d}$ in growing pigs (Batterham \& O'Neill, 1978). Also, it is possible that the response to supplemental lysine is curvilinear with a lower response as the requirement of the pig is approached (Agricultural Research Council, 1981).

The availability of lysine in pig diets has been estimated by the slope ratio assay (Batterham et al. 1979). Values of $0.62,0.66$ and 0.88 , when weight gains were the response criterion, were found for the protein concentrates cotton-seed meal, meat meal and skim milk respectively. The relative weight gains in the present experiment for these three protein concentrates were found to be $0 \cdot 62,0 \cdot 80$ and $1 \cdot 00$, showing a similar trend to that observed by Batterham et al. (1979).

In the present experiment, diets 6-10 were supplemented with free lysine $(3 \mathrm{~g} / \mathrm{kg})$. The results confirmed that lysine was the first limiting amino acid in all diets. Growth rates were increased by an average of $140 \%$. The increase was $188 \%$ when meat meal was the protein concentrate and only $110 \%$ when the protein concentrate was milk. This could indicate a lower availability of lysine in meat meal than in milk, assuming free lysine is fully available.

The performance of pigs given the diets containing the meat meal protein concentrate was less than that of the pigs given the other eight diets, even when all diets contained $10.9 \mathrm{~g}$ lysine $/ \mathrm{kg}$. This would also suggest that the availability of lysine in meat meal is lower than in the other protein concentrates or that the lysine requirement of the pigs was greater than $10.9 \mathrm{~g} / \mathrm{kg}$ diet from wheat and meat meal. In fact, a value of $13.26 \mathrm{~g}$ lysine $/ \mathrm{kg}$ of a weaner diet containing 13.54 MJ digestible energy $/ \mathrm{kg}$ (the mean value of the diets used in this study) was recommended by the Agricultural Research Council (1981), compared with a value of $9.5 \mathrm{~g}$ lysine $/ \mathrm{kg}$ diet recommended by the (US) National Research Council (1979). Another possibility is that once excess lysine is given then another amino acid, which could be tryptophan, becomes limiting for the diets containing meat meal as the protein concentrate (Leibholz, 1982a).

The apparent digestibility of $\mathrm{N}$ to the ileum was lower for the diets containing cotton-seed meal and meat meal than that of the diets containing milk. If allowance is made for the contribution of the protein concentrates to the total diets then the differences are more than $20 \%$. Tanksley et al. (1981) also found a low apparent digestibility for $\mathrm{N}$ to the ileum for cotton-seed meal while the results for meat meal agree with the report of Taverner et al. (1983). When considering the digestibility of lysine to the ileum the values for the diets 
containing meat meal and cotton-seed meal were also lower than those for the diets containing milk.

The apparent digestion of lysine to the ileum was significantly $(P<0.05)$ less than that to the large intestine and, presumably, the faeces, although lysine was not measured in the faeces. This disappearance of lysine in the hind-gut in pigs given commercial diets was also observed by Holmes et al. (1974) and Wünsche et al. (1979) who found that about 10\% of the total apparent absorption of lysine occurred in this area. However, with purified diets there was little difference between the flow of $\mathrm{N}$ and lysine to the ileum and faeces as was the case for a number of diets given to growing pigs by Sauer et al. (1980) and Low (1979). Part of the explanation of differences in these results may be due to the method of collection of ileal samples. In the present experiment, the pigs were slaughtered and samples were collected from the last third of the intestine, while in the other studies ileal contents were collected from ileal cannulas placed at the distal end of the ileum. Even with re-entrant cannulas, the method of sample collection, at least at the duodenum, has been shown to influence the results (Low \& Zebrowska, 1977).

There was no apparent absorption of DM from the stomach. The jejunum, or middle third of the small intestine, was the major site of absorption which agrees with the observations of Zebrowska (1975). For $\mathrm{N}$, an average of $52 \%$ of apparent digestion occurred to the jejunum compared with $57 \%$ for DM. These values are similar to those of Zebrowska (1975) with growing pigs but values for younger pigs, $27 \mathrm{~d}$ of age, showed that the major site of DM absorption was the first third of the small intestine (duodenum) while that of $\mathrm{N}$ was the duodenum and jejunum (Leibholz, 1982b). This may be explained by both the carbohydrate source in the diets, lactose $v$. wheat, and the age of the pigs.

The site of both $\mathrm{N}$ and DM absorption was also influenced by the type of protein concentrate in the diet. When meat meal was given, the sites of absorption were lower in the digestive tract than for the other sources of protein. The same observation was made by Alimon \& Farrell (1980). This may be explained by the accessibility of the digestive enzymes to the different proteins and differences in the rates of hydrolysis of the proteins by the enzymes.

In the calculations made in the preparation of Table 6, the lysine content of the pig carcasses was taken as the mean of the values of Wilson \& Leibholz (1981b), and this is similar to other values in the literature (e.g. Williams et al. 1954; Aumaitre \& Duée, 1974). The amino acid composition of carcass protein has been shown not to alter greatly with age of pigs or with diet (Williams et al. 1954; Aumaitre \& Duée, 1974; Wilson \& Leibholz, $1981 \mathrm{~b}$ ). The protein content of the carcasses was taken from a previous experiment by Leibholz (1985) with pigs of similar age, offered similar diets.

The apparent digestibility of lysine to the ileum was calculated for pigs between 51 and $56 \mathrm{~d}$ of age. This digestibility value was applied to the weight gains of pigs from 23 to $51 \mathrm{~d}$ of age, in the calculation of the retention of the apparently absorbed lysine in weight gain (Table 6).

The retention of $\mathrm{N}$ and lysine in the carcass of pigs is influenced by the balance of amino acids in the diet in relation to the amino acid requirement of the animal for maintenance and growth. This means that a high efficiency of incorporation of an amino acid into the carcass would indicate that the amino acid may be limiting for growth. In the present experiment, the calculated efficiency of incorporation of apparently absorbed lysine into weight gain was about $90 \%$, which may indicate lysine as the first limiting amino acid, especially as the mean overall retention of absorbed $\mathrm{N}$ was only $48-58 \%$. The retention of $\mathrm{N}$ from the milk diet was greater than that from other diets, indicating a better amino acid profile for this diet which was also of a lower CP content than the other four diets. The mean values for the retention of $\mathrm{N}$ were similar to the values of $30-39 \%$ reported by 
Hodge (1974) and $48-67 \%$ by Leibholz (1985) for pigs of similar age and weight. The high retention of absorbed lysine in weight gain suggests that very efficient utilization of absorbed lysine occurred from all five protein concentrates and it is therefore suggested that the availability of lysine may be predicted from its digestibility to the ileum. Similar suggestions were made for methionine by Achinewhu \& Hewitt (1979) and Leibholz (1985).

The apparent digestibilities of methionine, threonine and isoleucine as well as lysine to the ileum were lower for meat meal and cotton-seed meal than for the other three protein concentrates. It is suggested that the digestibility of these amino acids to the ileum may also be an indicator of their availability. There was no significant difference $(P>0.05)$ between the digestibilities of the other essential amino acids for the five protein concentrates. The availability of lysine is often used as an indicator of availability of all essential amino acids but this may only apply for lysine, methionine, threonine and isoleucine.

It may be concluded that there are differences in the availability of lysine found in a number of protein concentrates and that these differences may be predicted from values obtained from their digestibility to the ileum.

This study was made possible by the support of the Australian Pig Industry Research Committee. The author also wishes to thank Associate Professor Yong Chin Li, Mrs Robyn Smith and Dr Y. Mollah for assistance in all aspects of this work.

\section{REFERENCES}

Achinewhu, S. C. \& Hewitt, D. (1979). British Journal of Nutrition 41, 559-571.

Agricultural Research Council (1981). The Nutrient Requirements of Pigs. Slough: Commonwealth Agricultural Bureaux.

Alimon, A. R. \& Farrell, D. J. (1980). Australian Journal of Agricultural Research 31, 627-635.

Aumaitre, A. \& Duée, P. H. (1974). Annales de Zootechnie 23, 231-241.

Batterham, E. S., Murison, R. D. \& Lewis, L. E. (1978). British Journal of Nutrition 40, 23-28.

Batterham, E. S., Murison, R. D. \& Lewis, L. E. (1979). British Journal of Nutrition 41, 383-391.

Batterham, E. S. \& O'Neill, G. H. (1978). British Journal of Nutrition 39, 265-270.

Carpenter, K. J. (1960). Biochemistry Journal 77, 604-610.

Hodge, R. W. (1974). British Journal of Nutrition 32, 113-126.

Holmes, J. H. G., Bayley, H. S., Leadbeater, P. A. \& Horney, F. D. (1974). British Journal of Nutrition 32, $479-489$.

Leibholz, J. (1982a). Animal Feed Science and Technology 7, 27-34.

Leibholz, J. (1982b). British Journal of Nutrition 48, 509-517.

Leibholz, J. (1985). British Journal of Nutrition 53, 137-147.

Low, A. G. (1979). British Journal of Nutrition 41, 147-156.

Low, A. G. \& Zebrowska, T. (1977). British Journal of Nutrition 38, 145-152.

National Research Council (1979). Nutrient Requirements of Domestic Animals No. 2, Nutrient Requirements of Swine, 8th ed. Washington, DC: National Academy of Sciences.

Sauer, W. C., Just, A., Jorgensen, H. H., Fekadu, M. \& Eggum, B. O. (1980). Acta Agriculturae Scandinavica 30, 449-459.

Steel, R. G. D. \& Torrie, J. H. (1960). Principles of Statistics. New York: McGraw-Hill Book Co.

Tanksley, T. D., Knabe, D. A., Purser, K., Zebrowska, T. \& Carley, J. R. (1981). Journal of Animal Science 52, 769-777.

Taverner, M. R., Curic, D. M. \& Rayner, C. J. (1983). Journal of the Science of Food and Agriculture 34, $122-128$.

Williams, H. H., Curtin, L. V., Abraham. J., Loosli, J. K. \& Maynard, L. A. (1954). Journal of Biological Chemistry 208, 277-285.

Wilson, R. H. \& Leibholz, J. (1981 a). British Journal of Nutrition 45, 321-326.

Wilson, R. H. \& Leibholz, J. (1981 b). British Journal of Nutrition 45, 359-366.

Wünsche, J., Bock, H. D., Hennig, V., Kreinenbring, F. \& Bergmann, E. (1979). Archiv für Tierernährung 29, 221-234.

Zebrowska, T. (1975). Roczniki Nauk Rolniczych, Seria B 96, 79-90. 